\title{
Review \\ The Chemokine Systems at the Crossroads of Inflammation and Energy Metabolism in the Development of Obesity
}

\author{
Pei-Chi Chan ${ }^{1}\left[\right.$ and Po-Shiuan Hsieh ${ }^{1,2,3, *}$ \\ 1 National Defense Medical Center (NDMC), Department of Physiology \& Biophysics, Taipei 114, Taiwan; \\ peggychan7@gmail.com \\ 2 Graduate Institute of Medical Science, NDMC, Taipei 114, Taiwan \\ 3 Department of Medical Research, Tri-Service General Hospital, Taipei 114, Taiwan \\ * Correspondence: pshsieh0465@gmail.com; Tel.: +886-2-87923100 (ext. 18622); Fax: +886-2-87924827
}

check for updates

Citation: Chan, P.-C.; Hsieh, P.-S.

The Chemokine Systems at the

Crossroads of Inflammation and

Energy Metabolism in the

Development of Obesity. Int. J. Mol.

Sci. 2021, 22, 13528. https://doi.org/

$10.3390 /$ ijms222413528

Academic Editor: Yoshiro Kobayashi

Received: 15 November 2021

Accepted: 13 December 2021

Published: 16 December 202

Publisher's Note: MDPI stays neutral with regard to jurisdictional claims in published maps and institutional affiliations.

Copyright: (C) 2021 by the authors Licensee MDPI, Basel, Switzerland. This article is an open access article distributed under the terms and conditions of the Creative Commons Attribution (CC BY) license (https:// creativecommons.org/licenses/by/ $4.0 /)$.

\begin{abstract}
Obesity is characterized as a complex and multifactorial excess accretion of adipose tissue accompanied with alterations in the immune and metabolic responses. Although the chemokine systems have been documented to be involved in the control of tissue inflammation and metabolism, the dual role of chemokines and chemokine receptors in the pathogenesis of the inflammatory milieu and dysregulated energy metabolism in obesity remains elusive. The objective of this review is to present an update on the link between chemokines and obesity-related inflammation and metabolism dysregulation under the light of recent knowledge, which may present important therapeutic targets that could control obesity-associated immune and metabolic disorders and chronic complications in the near future. In addition, the cellular and molecular mechanisms of chemokines and chemokine receptors including the potential effect of post-translational modification of chemokines in the regulation of inflammation and energy metabolism will be discussed in this review.
\end{abstract}

Keywords: chemokines; inflammation; energy metabolism; obesity

\section{Introduction}

The chemokines and seven-transmembrane $\mathrm{G}$ protein-coupled chemokine receptors have been documented to be the mediators of immune cell migration and response to the inflammatory reaction in injury and infection. Chemokines have also been reported to coordinate recruitment of various cell types in adipose tissues such as immune cells, adipocyte progenitors and endothelial cells in mice and humans [1]. The interaction between the chemokine system and these different cell types in brown and white adipose tissues (WAT) has been speculated to participate in the regulation of whole-body energy balance and glucose homeostasis [2-6]. However, the dynamic interaction between chemokines and different subsets of mesenchymal cells in the pathogenesis of the inflammatory milieu and dysregulated energy metabolism in obesity remains poorly understood.

Chemokines have been classified into CXC, CC, C and CX3C subfamilies in the base on the positioning of two amino-terminal cysteine residues. $X$ in the chemokine could be any amino acid residue. Chemokines could bind with one or more chemokine receptors and also trigger different responses due to variant binding affinities to chemokine receptors for distinct chemokine ligands [7]. In addition, post-translational modification of chemokines by interaction with the extracellular matrix (ECM) and by binding to cell surfaces could significantly affect biological actions of chemokines and chemokine receptors. This review aims to present a significant updated study about the physiological and pathological roles of chemokines in energy metabolism and inflammation in the states of normal weight and obesity and the possible underlying mechanisms. 


\section{Chemokines in Obesity and Metabolic Syndrome}

The increase in prevalence of obesity and associated cardiometabolic diseases has become a priority issue in health care systems worldwide and contributes to the global economic burden. Adipose tissue expansion in obesity consists of white and brown adipose tissues. WAT is the predominant site of energy storage and also serves as the endocrine organ. The adipocyte-derived hormones, cytokines and growth factors could regulate cell functions on local and/or systemic levels. Brown adipose tissue (BAT) is rich in mitochondria and capable of increasing energy expenditure and adaptive thermogenesis mainly via the activity of uncoupling protein 1 (UCP-1) [8]. There are some subcutaneous WATs possessing a subset of cells called beige adipocytes that can express high levels of UCP- 1 upon chronic exposure to cold and $\beta$-adrenergic stimulation. Thereby, these cells are capable of elevated fuel oxidation and thermogenesis if needed. On the other hand, the chemokine levels in adipose tissue could be upregulated by the augmentation of inflammatory mediators in the obese adipose tissues [9-11]. However, it still remains elusive about the role of chemokines in deteriorating the development of adipose tissue dysfunction and insulin resistance in humans.

Previous reports have demonstrated that chemokines can facilitate the development of morbid obesity through its receptors to promote inflammatory leukocyte influx, especially pro-inflammatory monocytes, into hypertrophic adipose tissue. Circulating levels and tissue contents of the chemokines such as CXCL1, CXCL5, CXCL8, CXCL12, CCL2, CCL5, CCL7 and CCL19 are significantly increased in obesity. Abrogation of the signal pathways of CXCL14, CXCL5, CCL2, or their cognate chemokine receptors, alleviated obesity-associated metabolic abnormalities in high fat diet (HFD)-induced obese mice [1,12]. For instance, the study conducted with HFD-induced obese mice showed that deletion of CCL2 or its receptor CCR2 significantly attenuated inflammatory macrophage (ATM) infiltration and inflammatory reaction in adipose tissues [13-15] and consistent overexpression of CCL2 in adipose tissue increased inflammatory ATM content in WAT [16]. Nevertheless, deletion of CCL2 gene did not affect obesity-associated monocyte influx into WAT [17]. On the other hand, previous reports have demonstrated that the increases of the expression CCL7 [18] in adipose tissues not only promotes migration of prostate cancer cells but also participates in a link between adipose tissue inflammation and insulin resistance in HFD-induced obese mice and the murine 3T3-F442A pre-adipocyte cell line. Increased adipose tissue expression of CCL19 in obese subjects has also been implicated to represent a pathological link between systemic low-grade inflammation and insulin resistance [19]. Taken together, these observations demonstrate that the chemokines/chemokine receptor-mediated signaling substantially contribute to the development of adipose tissue inflammation and subsequent metabolic disorders in obesity. However, the dualistic role of chemokines and chemokine receptors in the etiology of obesity-related inflammation and energy metabolism has been speculated on, but the data remain ambiguous.

\section{The Involvement of Chemokines and Chemokine Receptors in the Development of Inflammation and Energy Metabolism}

Metabolism homeostasis has been believed to be affected by cytokines secreted by immune cells as well as by adipocytes themselves in adipose tissue. Augmentation of tissue inflammation through adipocyte release of chemokines (e.g., CCL2 [13], CCL5 [20]) drives the alteration in leukocyte number and phenotype, thereby expanding the inflammatory environment within adipose tissue beds. The pro-inflammatory signals are also the important components of the thermogenic regulation in brown and beige adipocytes and contribute to their dysfunction in obesity by impairing energy expenditure and glucose uptake. In contrast, brown adipocytes release chemokines such as CXCL14- recruited, alternatively activated (M2) macrophages, and exerts its effects on promoting energy metabolism [21]. It is implicated that chemokines and chemokine receptors play a double-edged role in the progression of adipose tissue inflammation and energy metabolism, as shown in Figure 1. 


\section{Chemokines}

(+) Inflammation

( \pm ) Energy metabolism

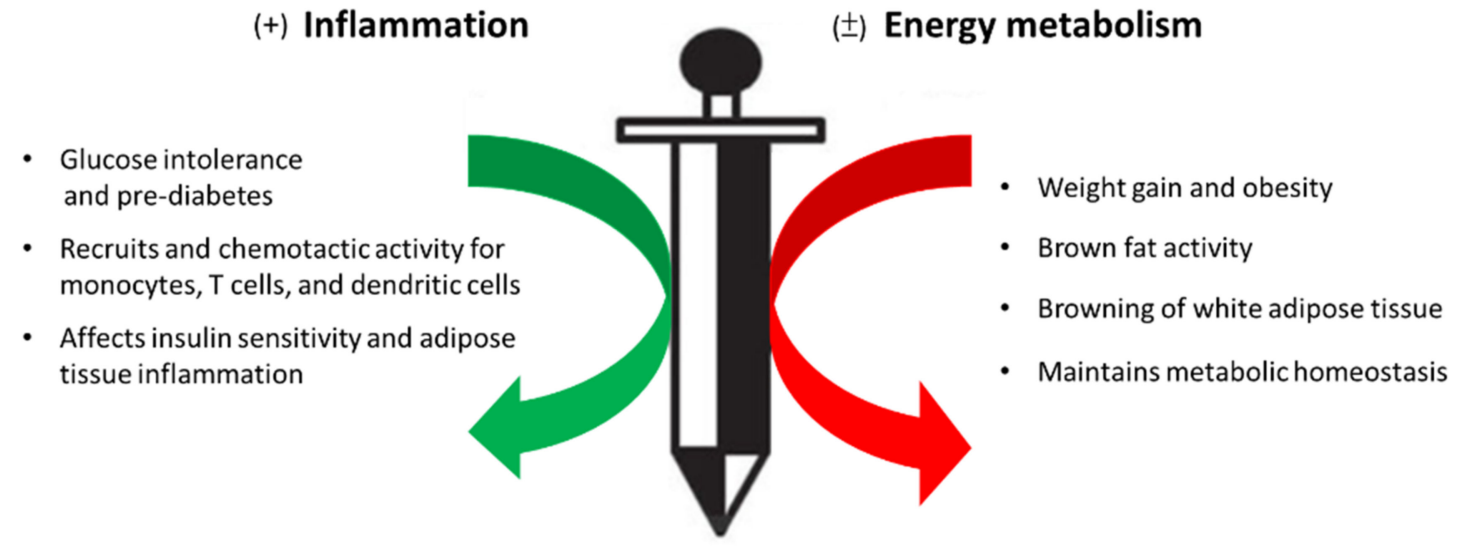

Figure 1. Chemokines, a double-edged sword in the inflammatory response and energy metabolism during the process of metabolic syndrome.

\subsection{CCL5}

CCL5, also known as RANTES, has been documented to be involved in the pathogenesis of many inflammatory conditions in vivo. CCL5 could activate downstream signaling pathways such as nuclear factor NF- $\mathrm{KB}$, and mitogen activated protein kinase (MAPK) pathways through its receptors, namely, CCR1, CCR3, and CCR5 [22-24]. In diabetes patients, CCL5 and CCR5 are upregulated in the peripheral blood $[25,26]$ and they have also been well-documented as the upstream regulators of insulin resistance in obese individuals [27]. Besides, the increased serum levels of CCL5 in type 2 diabetic patients were closely related to postprandial hyperglycemia [28]. The onset of cardiovascular diseases in middle-aged females has been shown to be correlated to the CCL5 level in adipose tissue [29]. Augmented expression of CCL5 has been demonstrated to mediate the arrest and transmigration of monocytes/macrophages into the damaged site by binding with its receptor CCR5 [24,30,31]. CCL5 has also been reported to be involved into inflammatory reaction of WAT by recruiting blood monocytes and exerting antiapoptotic properties on WAT macrophages in obese subjects [20]. Moreover, Kim et al. reported that UV-induced CCL5 can suppress triglyceride synthesis in human adipocytes via downregulation of lipogenic enzymes. These observations suggest that CCL5 may participate in the pathogenesis of obesity-associated dysregulation of lipid metabolism and comorbidities [32].

On the other hand, CCL5 has also been reported to participate in the central control of energy metabolism in addition to their roles in mediating inflammation. Chou and colleagues showed that the hypothalamic CCL5/CCR5 signaling through the regulation of glucose uptake and AMPK activity might link to systemic insulin dependent glucose metabolism [33]. Furthermore, a clinical study evaluated the expression changes of CCL5 and CCR5 in obese humans under physical exercise. Their result showed that expression of CCL5 and CCR5 was higher in the subcutaneous adipose tissue of obese individuals compared with lean control and the elevated expression of CCL5 and CCR5 was significantly reversed through physical exercise [34]. Our recent study has demonstrated that obesity-induced augmentation of CCL5/CCR5 signaling suppressed adaptive thermogenesis by inhibiting AMPK-mediated lipolysis and oxidative metabolism in BAT to deteriorate the development of obesity [35]. However, the role of the CCL5-mediated signaling and whole-body energy metabolism still needs to be clarified further.

\subsection{CX3CL1-CX3CR1 Signaling}

CX3CL1, also known as fractalkine, is a chemokine with chemotactic activity for monocytes, T cells, and NK cells in the development of numerous inflammatory conditions in obesity-associated chronic complications such as atherosclerosis, insulin resistance and 
Type 2 diabetes [36-38]. For instance, the elevated CX3CL1 level has been reported in the blood of patients with type 2 diabetes and obesity [37]. CX3CL1 has been demonstrated to promote monocyte adhesion to human adipocytes as well as to evoke adipose tissue inflammation [37]. A study has shown that CX3CL1-mediating early recruitment of microglia induced by HFD might contribute to the induction of hypothalamic inflammatory response and subsequently the impairment of glucose tolerance and adiposity in experimental obesity [39]. Nevertheless, the role of the CX3CL1-CX3CR1 system in obesity-associated adipose tissue inflammation and insulin resistance remains controversial. For instance, CX3CR1 deficient mice were protected against the development of HFD-induced obesity and WAT inflammation [40]. Deficiency of CX3CL1-CX3CR1 signaling resulted in the reduction of M2-polarized macrophage migration and an M1-dominant shift of macrophages within WAT. Moreover, mice lacking CX3CR1 expression with HFD feeding displayed the reduced expression of proinflammatory cytokines and improved the profile of proteins involved in lipid metabolism and thermogenesis in BAT [41]. However, CX3CL1 administration in vivo has been reported to have a contradictory effect in diminishing glucose intolerance and insulin resistance [42]. Lee and colleagues also showed that $C X 3 C R 1^{-/-}$ mice developed glucose intolerance with diminished insulin secretion on both regular chow and HFD. CX3CR1 deletion also promoted proinflammatory macrophage accumulation in adipose tissue and liver as well as insulin resistance [38]. Moreover, Nagashimada et al. reported that glucose intolerance, insulin resistance, and hepatic steatosis induced by HFDinduced obesity or leptin deficiency were exacerbated in $C X 3 C R 1^{-/-}$mice. Thus, these contradictory observations implicate the dualistic role of the CX3CL1-CX3CR1 signaling in obesity-associated dysregulated glucose metabolism and adipose tissue inflammation. However, the underlying mechanism remains unclear.

\subsection{CXCL12-CXCR4 Signaling}

CXCL12, also known as stromal cell-derived factor 1 (SDF1), initially is a chemokine identified in bone marrow-derived stromal cells [43] and also an adipocyte-derived chemokine [44]. CXCL12 could regulate cell migration and survival through its receptor CXCR4 during cell development and tissue re-modeling [45]. Furthermore, blockage of CXCL12 action could reduce macrophage accumulation in adipose tissue via its receptor CXCR4 and eventually improved systemic insulin resistance in mice [44]. The CXCR4 in WAT has been reported to contribute to obesity-induced leukocyte recruitment, homeostasis, adipose tissue inflammation, and functional responses of adipocytes [46,47]. Moreover, the CXCL12-CXCR4 pathway has recently been speculated to be involved in the regulation of energy metabolism. For example, CXCL12-CXCR4 axis in adipose progenitors (APCs) has been demonstrated to contribute to ectopic fat deposition in highfat fed mice through their migration to skeletal muscle to differentiate into adipocytes from subcutaneous fat [48]. Pharmacological antagonism of CXCR4 could prevent the effect of CXCL12 on APCs in subcutaneous fat and mimic the effects of overfeeding. A study conducted with CXCR4 Loxp mouse and fatty acid-binding protein 4 -Cre mice has shown that CXCR4 deficiency in either adipocyte or myeloid leukocyte could facilitate body weight gain and adiposity in HFD-induced obese mice through enhancing macrophage infiltration into the WAT and hypo-activity of brown adipocytes [46]. Accordingly, the UCP-1 mRNA and protein levels and oxygen consumption were significantly increased in the brown adipocytes treated with CXCL12 peptide [49]. In addition, the CXCL12-CXCR4 pathway has been further shown to participate in the control of adaptive thermogenesis and metabolic homeostasis through the activation of brown adipocytes in response to over-nutrition or intake of HFD [49]. In brief, the CXCL12CXCR4 pathway could potentially affect several physiological processes related to the regulation of energy metabolism in adipose tissues. 


\subsection{CXCL14}

The enhanced expression of CXCL14 was noted in WAT of HFD-fed obese mice. CXCL14 deletion could reduce proinflammatory macrophage infiltration in WAT and improved insulin sensitivity in HFD-fed female mice [50]. CXCL14 deficiency could diminish HFD-induced hyperglycemia, hyperinsulinemia, hypo-adiponectinemia and hepatic steatosis in mice $[50,51]$. In addition, overexpression of CXCL14 in skeletal muscle restored obesity-induced insulin resistance in CXCL14 ${ }^{-/-}$mice [50,52]. It is implicated that CXCL14 is important not only in the regulation of insulin-dependent glucose uptake in skeletal muscles but also in control of whole-body glucose metabolism. Nevertheless, the in vitro study has also shown that CXCL14 has the pro-diabetogenic effects to inhibit glucose-stimulated insulin secretion in mouse islets [53].

Intriguingly, a research team found a causal link between CXCL14 protein and the regulation of energy metabolism. In their study, thermogenic stimuli led to the increase in CXCL14 levels and also the release of CXCL14 by BAT, which exhibits potential beneficial effects to obesity-associated metabolic diseases such as metabolic syndrome and type 2 diabetes. In addition, the authors have further demonstrated that CXCL14 might have a protective effect against insulin resistance by promoting the recruitment of alternatively activated M2 macrophages to adipose tissues and subsequently promote brown fat activity and white fat browning in subcutaneous adipose tissue [21]. However, there was a contradictory report that HFD-induced upregulation of CXCL14 could enhance insulin sensitivity by affecting adipocyte insulin signaling [54].

\section{The Cellular and Molecular Mechanisms of Chemokines and Chemokine Receptors in the Regulation of Inflammation and Energy Metabolism}

To elucidate the cellular and molecular mechanisms of chemokines and chemokine receptors in control of inflammation and energy metabolism under physiological and pathological conditions is crucial for developing therapeutic strategies for obesity-associated immune and metabolic disorders and chronic complications. However, the underlying mechanisms are not yet fully understood. In this session, we summarized the current understanding of the mechanism underlying the potential role of the chemokine systems on inflammation and energy metabolism. It might lead to future drug development for treatment of chemokine-related diseases, especially obesity-associated cardiometabolic disorders. On the other hand, there are two families of chemokine receptors in response to chemokine binding: conventional chemokine receptors (cCKRs) and atypical chemokine receptors (ACKRs). Chemokine-bound cCKRs typically transduce signals through pertussis toxin-sensitive GaiG-proteins and $\beta$-arrestins, ultimately leading to cell migration, adhesion and/or a variety of other biological responses. ACKRs are structurally related to cCKRs but do not couple to the G-protein-mediated signal transduction pathways activated by cCKRs $[7,55]$. They both could modulate biological effects of chemokines on tissue inflammation and energy metabolism.

\subsection{The Cellular and Molecular Mechanisms of Chemokine-Mediated Tissue Inflammation}

Tissue inflammation is attributed to local immune, vascular and inflammatory cell responses to acute infection or injury and also exhibits in chronic inflammatory diseases such as autoimmune diseases [56-58], allergy [59], neuron degeneration disease [60], chronic inflammatory disease [61], cardiovascular disease [62], cancer [63] and morbid obesity [64]. Chemokines are multifunctional mediators mainly responsible for leukocyte recruitment to inflamed organ systems and control the innate immune cell trafficking between the bone marrow, blood, and peripheral tissues during inflammation through chemokine receptors. These inflammatory chemokine profiles typically include cCKRs such as CCR1, CCR2, CCR3, CCR5, CXCR1, CXCR2, and CXCR3 and ACKRs such as ACKR1, and ACKR2. However, the precise chemokine profile in a given tissue is depend on the exact nature of the chemokine network in the affected individual and also the received stimuli. 
For instance, glucotoxicity that occurs in both type 1 and type 2 diabetes could facilitate the synthesis and release of chemokines by activating pancreatic $\beta$-cell NLRP3 inflammasomes [65] and the downstream inflammatory signal pathways such as IL1R and NF- $\mathrm{KB}$ [66]. During hepatic inflammation, both hepatocytes, stellate cells, sinusoidal endothelial cells and infiltrating leukocytes are the source of CXCR3 ligands. The expression of CXCR3 ligands requires stimulation with IFN- $\gamma$ and TNF- $\alpha$, which are released by activated hepatic macrophages, Kupffer cells and the initial wave of infiltrating innate immune cells $[67,68]$. Growing evidence has revealed that obesity is associated with immune response involving chemokines secreted by immune cells, such as CCL2, and CCL5. These proinflammatory chemokines could aggravate systemic inflammation by recruiting pro-inflammatory M1 macrophages, and contributes to the onset of obesityassociated comorbidities $[12,13,20]$. Moreover, Th1 and CD8 T cells are elevated in adipose tissues of obese subjects, which are major IFN $\gamma$-expressing cells that accumulates in obesity. IFN- $\gamma$ stimulates the expression of pro-inflammatory chemokines in adipocytes as well as the M1 polarization of macrophages [69,70]. CC chemokines, CCL2, CCL3, and CCL5, elevated in the joints of patients with rheumatoid arthritis, coincide with the recruitment of monocytes and T cells into synovial tissues. CXCL10 and CXCL8 chemokines were also elevated in the plasma of patients with active rheumatoid arthritis similar to the Th1 associated proinflammatory cytokines TNF $\alpha$, and IL-6 [71,72].

\subsection{The Cellular and Molecular Mechanisms of Chemokine and Chemokine Effects on Energy Metabolism}

The role of CCL2 in regulating AMPK activity has been demonstrated. Inflammatory stimuli increase the production of CCL2 and, subsequently, decrease the activation of AMPK, resulting in increased mTOR activity and, ultimately, altered energy metabolism [73]. Adipocyte CCL19 inhibited AMPK $\alpha$ through activating extracellular signal-regulated kinase (ERK)1/2, resulting in impaired lipid metabolism and energy regulation [74].

Chemokine-mediated signaling such as CCL2 can activate the phosphoinositide 3-kinases (PI3Ks) pathway [73,75]. The PI3Ks family of proteins such as lipid kinases and its lipid product, phosphatidylinositol triphosphate, have been shown to be involved in different cell functions, including regulating proliferation, cell polarity, cell survival and chemotaxis [76-78]. In addition, PI3K/AKT signaling regulates glucose metabolism. Notably, chemokines and chemokine receptors such as CXCL8 and CXCR4 have been reported to activate the PI3K/AKT signaling through chemokine receptors in osteosarcoma and pancreatic cancer cells $[79,80]$. AKT can directly stimulate glucose transporter (GLUT) 1 and induces translocation of GLUT 4 to cell membrane to facilitate glucose uptake into mammalian cells. Phosphofructokinase 2 is a rate-determining enzyme of glycolysis can also be activated by AKT [81].

In the tumor microenvironment, CCL5 directly interacts with CCR5-expressing breast cancer cells to promote anabolic metabolic events leading to enhanced cell proliferation and tumorigenesis. On the other hand, CCL5 has been reported to regulate T cell rolling, adhesion, and transmigration efficiency to promote an effective immune response [82]. CCL5-mediated glucose uptake and ATP accumulation to meet the energy demands of chemotaxis in activated T cells [83]. In addition, it has also been demonstrated that CCL5 participates in macrophage chemotaxis. CCL5 enhanced RAW264.7 macrophage migration and glucose uptake through up-regulated membrane GLUT1 expression as well as phosphorylation of AKT which has prolonged effect on phosphorylation of AMPK [84]. However, the pathological and physiological roles of CCL5-mediated signaling in obesityrelated dysregulation of energy metabolism remain mostly unclear.

The CXCL12-CXCR4 pathway elicits brown adipocyte activity and affects nutrient metabolism through upregulation in p38 and ERK levels under energy overnutrition [49]. A novel regulatory factor, CXCL14, secreted by BAT in response to cold exposure, has been shown to increase energy expenditure through promoting M2 macrophages recruitment 
and browning of WAT and, eventually, could counterbalance the detrimental effect of energy excess under the state of energy overnutrition [21].

4.3. The Potential Effects of Post-Translational Modification of Chemokines on Inflammation and Energy Dysregulation in the Development of Obesity

Chemokines are profoundly affected by post-translational modification, which regulates chemokine localization and abundance by interaction with the ECM and by binding to cell surfaces. The complex physical interactions existing in the chemokine network could significantly affect biological actions of chemokines and chemokine receptors. The post-translational modification of chemokines such as citrullination [85-87], nitration/nitrosylation [88-90], and cleavage by matrix metalloproteinases (MMPs), cathepsins, thrombin, plasmin, elastase, the dipeptidyl peptidase CD26, and other proteases [91-93] can substantially modify chemokine activity. For instance, nitration of tyrosine residues in CCL2 by reactive nitrogen species reduces the ability of this chemokine to attract monocytes through its receptor CCR2 [88], which might be involved in obesity-induced adipose tissue inflammation [15]. Proteases such as dipeptidyl peptidase-4 (DPP4, also called CD26, cluster of differentiation 26) and MMPs are key chemokine regulators. DPP4-mediated trimming of two amino acids off a chemokine's $\mathrm{N}$ terminus can change receptor specificity, substantially alter chemokine receptor affinity or convert agonists into antagonists [91]. Many MMPs have similar effects as DPP4 on selected chemokines. MMP-mediated Nterminal trimming could enhance the activity of CXCR2 ligands, and of CC chemokines with extended N-termini (i.e., CCL6, CCL9, CCL23), while CXCL12 is inactivated by MMPs and CCR2 ligands are converted into receptor antagonists [94].

Glycosaminoglycans (GAGs) are long unbranched polysaccharides which are composed of repeating disaccharide units and also referred to as mucopolysaccharides due to their viscous and lubricating properties. Their ability to bind chemokines influences chemokine/receptor interactions and also the half-life of chemokines in vivo [94,95]. In addition, TNF-stimulated gene-6, a multifunctional protein secreted in response to proinflammatory stimuli by monocytes and endothelial cells, has been shown to mediate anti-inflammatory effects by inhibiting chemokine/GAG interactions to alter chemokine distribution and function [96,97]. On the other hand, chemokines can act as monomers and also form homodimers and heterodimers. They can contain one or more chemokine species via interactions with GAGs [98-102]. For example, human CXCL4 and CCL5 can heterodimerize or oligomerize with over 20 other chemokines from CC, CXC, and XC subfamilies, respectively [102]. Oligomerization has been demonstrated to involve into the mechanism underlying individual chemokines or mixtures of them in control leukocyte responses $[78,97,101-103]$. Thereby, blockage of specific interactions as mentioned above may be the therapeutic targets to treat chemokine-induced immune and metabolic disorders in obesity.

\section{Modulation of the Chemokine/Chemokine Receptor Axis as a Novel Approach for Treatment of Morbid Obesity}

The complex chemokine network composed of a large number of interacting ligands, receptors and regulatory proteins engaged in diverse cellular processes in different given organs may significantly contribute to obesity-associated adipose tissue inflammation and whole-body energy dysregulation. Accordingly, the importance of chemokines and chemokine receptors in obesity-related adipose tissue inflammation and subsequent development of insulin resistance has been well-documented. Recently, some chemokines and their receptors, as discussed above, have been speculated to have diverse effects on regulation of immune reaction and energy metabolism as shown in Table 1. For instance, C3XCL1 could promote inflammatory reactions but suppress energy expenditure in BAT and WAT. On the other hand, CXCL12 and CXCL14 could facilitate energy expenditure in BAT but suppress energy metabolism and also provoke inflammatory reaction in WAT. Thereby, the chemokine system could become the potential therapeutic target of obesityassociated immune-metabolic abnormalities to prevent the development of obesity-related 
chronic complications such as metabolic syndrome, type 2 diabetes and cardiovascular diseases [104].

Table 1. The summary of the functional roles of adipocyte-derived chemokines.

\begin{tabular}{|c|c|c|c|c|c|c|c|c|}
\hline \multirow{3}{*}{ Chemokines } & \multirow{3}{*}{$\begin{array}{l}\text { Chemokine } \\
\text { Receptors }\end{array}$} & \multicolumn{3}{|c|}{ Brown/Beige Adipocytes } & \multicolumn{3}{|c|}{ White Adipocytes } & \multirow{3}{*}{ References } \\
\hline & & \multicolumn{2}{|c|}{ Inflammation } & \multirow{2}{*}{$\begin{array}{c}\text { Energy } \\
\text { Expenditure }\end{array}$} & \multicolumn{2}{|c|}{ Inflammation } & \multirow{2}{*}{$\begin{array}{c}\text { Energy } \\
\text { Expenditure }\end{array}$} & \\
\hline & & Pro & Anti & & Pro & Anti & & \\
\hline CCL5 & CCR5 & $\uparrow$ & $\downarrow$ & $\downarrow$ & $\uparrow$ & $\downarrow$ & $\downarrow$ & [30-35] \\
\hline C3XCL1 & CX3CR1 & $\uparrow$ & $\downarrow$ & $\downarrow$ & $\uparrow$ & $\downarrow$ & $\downarrow$ & [37-42] \\
\hline CXCL12 & CXCR4 & NA & NA & $\uparrow$ & $\uparrow$ & $\downarrow$ & $\downarrow$ & {$[44,46-49]$} \\
\hline CXCL14 & NA & NA & NA & $\uparrow$ & $\uparrow$ & $\downarrow$ & $\downarrow$ & {$[50-54]$} \\
\hline
\end{tabular}

For example, administration of TAK-779, a dual inhibitor of chemokine receptors CCR2 and CCR5, has been demonstrated to suppress obesity-related accumulation of leukocytes in the adipose tissue and be an efficient way to prevent insulin resistance and beta-cell dysfunction [105]. Compounds such as INCB8761/PF-413630 targeting adipose tissue in the treatment of obesity-associated diabetes, are currently pursued in human clinical trials and appear to be a new series of CCR2 antagonists that are orally bioavailable [106]. In brief, although clinical translation is still under slow progression, drugs targeting cCKRs in the development of obesity could be the potential therapeutic drug targets to made it to the clinic in the near future.

Author Contributions: P.-C.C. developed the first manuscript draft; P.-S.H. reviewed, revised, and approved the final version of the manuscript. All authors have read and agreed to the published version of the manuscript.

Funding: This study was supported by the Ministry of Science and Technology, Taiwan under MOST107-2320-B-016-MY3, MOST 109-2320-B-016-016, and MOST 110-2320-B-016-003, the Tri-Service General Hospital under TSGH-C109-54 and TSGH-D-110107.

Institutional Review Board Statement: Not applicable.

Informed Consent Statement: Not applicable.

Data Availability Statement: All the data are presented in the manuscript.

Conflicts of Interest: The authors declare no conflict of interest.

\section{References}

1. Surmi, B.K.; Hasty, A.H. The role of chemokines in recruitment of immune cells to the artery wall and adipose tissue. Vasc. Pharmacol. 2010, 52, 27-36. [CrossRef] [PubMed]

2. Painter, J.D.; Akbari, O. Type 2 Innate lymphoid cells: Protectors in type 2 diabetes. Front. Immunol. 2021, 12, 727008. [CrossRef]

3. Mahlakõiv, T.; Flamar, A.-L.; Johnston, L.K.; Moriyama, S.; Putzel, G.G.; Bryce, P.J.; Artis, D. Stromal cells maintain immune cell homeostasis in adipose tissue via production of interleukin-33. Sci. Immunol. 2019, 4, 416. [CrossRef] [PubMed]

4. Bolus, W.; Hasty, A.H. Contributions of innate type 2 inflammation to adipose function. J. Lipid Res. 2019, 60, 1698-1709. [CrossRef]

5. Rao, R.R.; White, J.P.; Svensson, K.J.; Lou, J.; Lokurkar, I.; Jedrychowski, M.P.; Ruas, J.L.; Wrann, C.D.; Lo, J.C.; Camera, D.M.; et al. Meteorin-like is a hormone that regulates immune-adipose interactions to increase beige fat thermogenesis. Cell 2014, 5, 1279-1291.

6. Boulenouar, S.; Michelet, X.; Duquette, D.; Alvarez, D.; Hogan, A.E.; Dold, C.; O'Connor, D.; Stutte, S.; Tavakkoli, A.; Winters, D.; et al. Adipose type one innate lymphoid cells regulate macrophage homeostasis through targeted cytotoxicity. Immunity 2017, 46, 273-286. [CrossRef] [PubMed]

7. Bachelerie, F.; Ben-Baruch, A.; Burkhardt, A.M.; Combadiere, C.; Farber, J.M.; Graham, G.J.; Horuk, R.; Sparre-Ulrich, A.H.; Locati, M.; Luster, A.D.; et al. International union of basic and clinical pharmacology. Update on the extended family of chemokine receptors and introducing a new nomenclature for atypical chemokine receptors. Pharmacol. Rev. 2013, 11, 1-79. [CrossRef]

8. Ikeda, K.; Yamada, T. UCP1 dependent and independent thermogenesis in brown and beige adipocytes. Front. Endocrinol. 2020, 11, 498. [CrossRef] 
9. Rakotoarivelo, V.; Variya, B.; Ilangumaran, S.; Langlois, M.-F.; Ramanathan, S. Inflammation in human adipose tissues-Shades of gray, rather than white and brown. Cytokine Growth Factor Rev. 2018, 44, $28-37$.

10. Rakotoarivelo, V.; Lacraz, G.; Mayhue, M.; Brown, C.; Rottembourg, D.; Fradette, J.; Ilangumaran, S.; Menendez, A.; Langlois, M.-F.; Ramanathan, S. Inflammatory cytokine profiles in visceral and subcutaneous adipose tissues of obese patients undergoing bariatric surgery reveal lack of correlation with obesity or diabetes. EBioMedicine 2018, 30, 237-247.

11. Pessentheiner, A.R.; Ducasa, G.M.; Gordts, P.L.S.M. Proteoglycans in obesity-associated metabolic dysfunction and metainflammation. Front. Immunol. 2020, 11, 769. [CrossRef] [PubMed]

12. Yao, L.; Herlea-Pana, O.; Heuser-Baker, J.; Chen, Y.; Barlic-Dicen, J. Roles of the chemokine system in development of obesity, insulin resistance, and cardiovascular disease. J. Immunol. Res. 2014, 2014, 181450. [CrossRef] [PubMed]

13. Kanda, H.; Tateya, S.; Tamori, Y.; Kotani, K.; Hiasa, K.-I.; Kitazawa, R.; Kitazawa, S.; Miyachi, H.; Maeda, S.; Egashira, K.; et al. MCP-1 contributes to macrophage infiltration into adipose tissue, insulin resistance, and hepatic steatosis in obesity. J. Clin. Investig. 2006, 116, 1494-1505. [CrossRef] [PubMed]

14. Chattopadhyay, D.; Das, S.; Guria, S.; Basu, S.; Mukherjee, S. Fetuin-A regulates adipose tissue macrophage content and activation in insulin resistant mice through MCP-1 and iNOS: Involvement of IFN $\gamma$-JAK2-STAT1 pathway. Biochem. J. 2021, 478, 4027-4043. [CrossRef]

15. Dommel, S.; Blüher, M. Does C-C motif chemokine ligand 2 (CCL2) link obesity to a pro-inflammatory state? Int. J. Mol. Sci. 2021, 22, 1500. [CrossRef]

16. Kamei, N.; Tobe, K.; Suzuki, R.; Ohsugi, M.; Watanabe, T.; Kubota, N.; Ohtsuka-Kowatari, N.; Kumagai, K.; Sakamoto, K.; Kobayashi, M.; et al. Overexpression of monocyte chemoattractant protein-1 in adipose tissues causes macrophage recruitment and insulin resistance. J. Biol. Chem. 2006, 281, 26602-26614.

17. Inouye, K.E.; Shi, H.; Howard, J.K.; Daly, C.H.; Lord, G.M.; Rollins, B.J.; Flier, J.S. Absence of CC chemokine ligand 2 does not limit obesity-associated infiltration of macrophages Into Adipose Tissue. Diabetes 2007, 56, 2242-2250. [CrossRef]

18. Laurent, V.; Guérard, A.; Mazerolles, C.; Le Gonidec, S.; Toulet, A.; Nieto, L.; Zaidi, F.; Majed, B.; Garandeau, D.; Socrier, Y.; et al. Periprostatic adipocytes act as a driving force for prostate cancer progression in obesity. Nat. Commun. 2016, $12,10230$.

19. Kochumon, S.; Al-Rashed, F.; Abu-Farha, M.; Devarajan, S.; Tuomilehto, J.; Ahmad, R. Adipose tissue expression of CCL19 chemokine is positively associated with insulin resistance. Diabetes Metab. Res. Rev. 2019, 35, e3087.

20. Keophiphath, M.; Rouault, C.; Divoux, A.; Clément, K.; Lacasa, D. CCL5 promotes macrophage recruitment and survival in human adipose tissue. Arter. Thromb. Vasc. Biol. 2010, 30, 39-45. [CrossRef]

21. Cereijo, R.; Gavaldà-Navarro, A.; Montserrat, C.; Quesada-López, T.; Villarroya, J.; Morón-Ros, S.; Sànchez-Infantes, D.; Peyrou, M.; Iglesias, R.; Mampel, T.; et al. CXCL14, a brown adipokine that mediates brown-fat-to-macrophage communication in thermogenic adaptation. Cell Metab. 2018, 28, 750-763.

22. Wang, S.-W.; Wu, H.-H.; Liu, S.-C.; Wang, P.-C.; Ou, W.-C.; Chou, W.-Y.; Shen, Y.-S.; Tang, C.-H. CCL5 and CCR5 interaction promotes cell motility in human osteosarcoma. PLOS ONE 2012, 7, e35101.

23. Long, H.; Xie, R.; Xiang, T.; Zhao, Z.; Lin, S.; Liang, Z.; Chen, Z.; Zhu, B. Autocrine CCL5 signaling promotes invasion and migration of CD133+ ovarian cancer stem-like cells via NF-kB-mediated MMP-9 upregulation. Stem Cells 2012, 30, $2309-2319$.

24. Li, M.; Sun, X.; Zhao, J.; Xia, L.; Li, J.; Xu, M.; Wang, B.; Guo, H.; Yu, C.; Gao, Y.; et al. CCL5 deficiency promotes liver repair by improving inflammation resolution and liver regeneration through M2 macrophage polarization. Cell. Mol. Immunol. 2020, $17,753-764$.

25. Slominski, B.; Lawrynowicz, U.; Ryba-Stanislawowska, M.; Skrzypkowska, M.; Mysliwska, J.; Mysliwiec, M. CCR5- $\triangle 32$ polymorphism is a genetic risk factor associated with dyslipidemia in patients with type 1 diabetes. Cytokine 2019, 114, 81-85.

26. Inayat, H.; Azim, M.K.; Baloch, A.A. Analysis ofinflammatory gene expression profile of peripheral blood leukocytes in type 2 diabetes. Immunol. Investig. 2019, 48, 618-631.

27. Ota, T. Chemokine systems link obesity to insulin resistance. Diabetes Metab. J. 2013, 37, 165-172. [CrossRef]

28. Dworacka, M.; Krzyzagorska, E.; Iskakova, S.; Bekmukhambetov, Y.; Urazayev, O.; Dworacki, G. Increased circulating RANTES in type 2 diabetes. Eur. Cytokine Netw. 2014, 25, 46-51.

29. Ahnstedt, H.; Roy-O'Reilly, M.; Spychala, M.S.; Mobley, A.S.; Bravo-Alegria, J.; Chauhan, A.; Aronowski, J.; Marrelli, S.P.; McCullough, L.D. Sex differences in adipose tissue CD8 + T Cells and regulatory T cells in middle-aged mice. Front. Immunol. 2018, 4, 659 .

30. Braunersreuther, V.; Pellieux, C.; Pelli, G.; Burger, F.; Steffens, S.; Montessuit, C.; Weber, C.; Proudfoot, A.; Mach, F.; Arnaud, C. Chemokine CCL5/RANTES inhibition reduces myocardial reperfusion injury in atherosclerotic mice. J. Mol. Cell. Cardiol. 2010, 48, 789-798.

31. Walens, A.; DiMarco, A.V.; Lupo, R.; Kroger, B.R.; Damrauer, J.S.; Alvarez, J.V. CCL5 promotes breast cancer recurrence through macrophage recruitment in residual tumors. eLife 2019, 16, e43653.

32. Kim, E.; Kim, Y.; Kim, S.; Kim, J.; Tian, Y.; Doh, E.; Lee, D.; Chung, J. Adipochemokines induced by ultraviolet irradiation contribute to impaired fat metabolism in subcutaneous fat cells. Br. J. Dermatol. 2018, 178, 492-501. [CrossRef] [PubMed]

33. Chou, S.-Y.; Ajoy, R.; Changou, C.A.; Hsieh, Y.-T.; Wang, Y.-K.; Hoffer, B. CCL5/RANTES contributes to hypothalamic insulin signaling for systemic insulin responsiveness through CCR5. Sci. Rep. 2016, 29, 37659. [CrossRef] [PubMed] 
34. Baturcam, E.; Abubaker, J.; Tiss, A.; Abu-Farha, M.; Khadir, A.; Al-Ghimlas, F.; Al-Khairi, I.; Cherian, P.; Elkum, N.; Hammad, M.; et al. Physical exercise reduces the expression of RANTES and its CCR5 receptor in the adipose tissue of obese humans. Mediat. Inflamm. 2014, 2014, 627150. [CrossRef]

35. Chan, P.-C.; Hung, L.-M.; Huang, J.-P.; Day, Y.-J.; Yu, C.-L.; Kuo, F.-C.; Lu, C.-H.; Tian, Y.-F.; Hsieh, P.-S. Augmented CCL5/CCR5 signaling in brown adipose tissue inhibits adaptive thermogenesis and worsens insulin resistance in obesity. Clin. Sci. 2021 [CrossRef]

36. Apostolakis, S.; Spandidos, D. Chemokines and atherosclerosis: Focus on the CX3CL1/CX3CR1 pathway. Acta Pharmacol. Sin. 2013, 34, 1251-1256. [CrossRef]

37. Shah, R.; Hinkle, C.C.; Ferguson, J.F.; Mehta, N.N.; Li, M.; Qu, L.; Lu, Y.; Putt, M.E.; Ahima, R.S.; Reilly, M.P. Fractalkine is a novel human adipochemokine associated with type 2 diabetes. Diabetes 2011, 60, 1512-1518. [CrossRef]

38. Lee, Y.S.; Morinaga, H.; Kim, J.J.; Lagakos, W.; Taylor, S.; Keshwani, M.; Perkins, G.; Dong, H.; Kayali, A.G.; Sweet, I.R.; et al. The Fractalkine/CX3CR1 system regulates $\beta$ cell function and insulin secretion. Cell 2013, 153, 413-425. [CrossRef]

39. Morari, J.; Anhe, G.F.; Nascimento, L.F.; de Moura, R.F.; Razolli, D.; Solon, C.; Guadagnini, D.; Souza, G.; Mattos, A.H.; Tobar, N.; et al. Fractalkine (CX3CL1) is involved in the early activation of hypothalamic inflammation in experimental obesity. Diabetes 2014, 63, 3770-3784. [CrossRef]

40. Polyak, A.; Ferenczi, S.; Denes, A.; Winkler, Z.; Kriszt, R.; Pinter-Kubler, B.; Kovacs, K.J. The fractalkine/Cx3CR1 system is implicated in the development of metabolic visceral adipose tissue inflammation in obesity. Brain Behav. Immun. 2014, 38, 25-35. [CrossRef]

41. Polyak, A.; Winkler, Z.; Kuti, D.; Ferenczi, S.; Kovacs, K.J. Brown adipose tissue in obesity: Fractalkine-receptor dependent immune cell recruitment affects metabolic-related gene expression. Biochim. Biophys. Acta 2016, 186, 1614-1622. [CrossRef]

42. Nagashimada, M.; Sawamoto, K.; Ni, Y.; Kitade, H.; Nagata, N.; Xu, L.; Kobori, M.; Mukaida, N.; Yamashita, T.; Kaneko, S.; et al. CX3CL1-CX3CR1 Signaling Deficiency Exacerbates Obesity-induced Inflammation and Insulin Resistance in Male Mice. Endocrinology 2021, 162, bqab064. [CrossRef]

43. Hill, W.D.; Hess, D.C.; Martin-Studdard, A.; Carothers, J.J.; Zheng, J.; Hale, D.; Maeda, M.; Fagan, S.C.; Carroll, J.E.; Conway, S.J. SDF-1 (CXCL12) is upregulated in the ischemic penumbra following stroke: Association with bone marrow cell homing to injury. J. Neuropathol. Exp. Neurol. 2004, 63, 84-96. [CrossRef]

44. Kim, D.; Kim, J.; Yoon, J.H.; Ghim, J.; Yea, K.; Song, P.; Park, S.; Lee, A.; Hong, C.P.; Jang, M.S.; et al. CXCL12 secreted from adipose tissue recruits macrophages and induces insulin resistance in mice. Diabetologia 2014, 57, 1456-1465. [CrossRef]

45. Burger, J.A.; Kipps, T.J. CXCR4: A key receptor in the crosstalk between tumor cells and their microenvironment. Blood 2006, 107, 1761-1767. [CrossRef]

46. Yao, L.; Heuser-Baker, J.; Herlea-Pana, O.; Zhang, N.; Szweda, L.I.; Griffin, T.M.; Barlic-Dicen, J. Deficiency in adipocyte chemokine receptor CXCR4 exacerbates obesity and compromises thermoregulatory responses of brown adipose tissue in a mouse model of diet-induced obesity. FASEB J. 2014, 28, 4534-4550. [CrossRef]

47. Hazan, U.; Romero, I.A.; Cancello, R.; Valente, S.; Perrin, V.; Mariot, V.; Dumonceaux, J.; Gerhardt, C.C.; Strosberg, A.D.; Couraud, P.-O.; et al. Human adipose cells express CD4, CXCR4, and CCR5 receptors: A new target cell type for the immunodeficiency virus-1? FASEB J. 2002, 16, 1254-1256. [CrossRef]

48. Girousse, A.; Gil-Ortega, M.; Bourlier, V.; Bergeaud, C.; Sastourné-Arrey, Q.; Moro, C.; Barreau, C.; Guissard, C.; Vion, J.; Arnaud, E.; et al. The release of adipose stromal cells from subcutaneous adipose tissue regulates ectopic intramuscular adipocyte deposition. Cell Rep. 2019, 27, 323-333. [CrossRef]

49. Kurita, K.; Ishikawa, K.; Takeda, K.; Fujimoto, M.; Ono, H.; Kumagai, J.; Inoue, H.; Yokoh, H.; Yokote, K. CXCL12-CXCR4 pathway activates brown adipocytes and induces insulin resistance in CXCR4-deficient mice under high-fat diet. Sci. Rep. 2019, 9, 6165. [CrossRef]

50. Nara, N.; Nakayama, Y.; Okamoto, S.; Tamura, H.; Kiyono, M.; Muraoka, M.; Tanaka, K.; Taya, C.; Shitara, H.; Ishii, R.; et al. Disruption of CXC motif chemokine ligand-14 in mice ameliorates obesity-induced insulin resistance. J. Biol. Chem. 2007, 282, 30794-30803. [CrossRef]

51. Tanegashima, K.; Okamoto, S.; Nakayama, Y.; Taya, C.; Shitara, H.; Ishii, R.; Yonekawa, H.; Minokoshi, Y.; Hara, T. CXCL14 deficiency in mice attenuates obesity and inhibits feeding behavior in a novel environment. PLoS ONE 2010, 5, e10321. [CrossRef]

52. Hara, T.; Nakayama, Y. CXCL14 and insulin action. Vitam. Horm. 2009, 80, 107-123. [CrossRef]

53. Atanes, P.; Hawkes, R.G.; Olaniru, O.E.; Ruz-Maldonado, I.; Amisten, S.; Persaud, S.J. CXCL14 inhibits insulin secretion Independently of CXCR4 or CXCR7 receptor activation or CAMP inhibition. Cell. Physiol. Biochem. 2019, 52, 879-892. [CrossRef]

54. Takahashi, M.; Takahashi, Y.; Takahashi, K.; Zolotaryov, F.N.; Hong, K.S.; Iida, K.; Okimura, Y.; Kaji, H.; Chihara, K. CXCL14 enhances insulin-dependent glucose uptake in adipocytes and is related to high-fat diet-induced obesity. Biochem. Biophys. Res. Commun. 2007, 364, 1037-1042. [CrossRef]

55. Nibbs, R.J.; Graham, G.J. Immune regulation by atypical chemokine receptors. Nat. Rev. Immunol. 2013, 13, 815-829. [CrossRef]

56. Vaillant, A.A.J.; Vashisht, R.; Zito, P.M. Immediate Hypersensitivity Reactions; StatPearls Publishing: Treasure Island, FL, USA, 2021.

57. Yao, C.; Narumiya, S. Prostaglandin-cytokine crosstalk in chronic inflammation. Br. J. Pharmacol. 2019, 176, 337-354. [CrossRef] [PubMed]

58. Tirone, M.; Tran, N.L.; Ceriotti, C.; Gorzanelli, A.; Canepari, M.; Bottinelli, R.; Raucci, A.; Di Maggio, S.; Santiago, C.; Mellado, M.; et al. High mobility group box 1 orchestrates tissue regeneration via CXCR4. J. Exp. Med. 2018, 215, 303-318. [CrossRef] 
59. Castan, L.; Magnan, A.; Bouchaud, G. Chemokine receptors in allergic diseases. Allergy 2016, 72, 682-690. [CrossRef]

60. Le Thuc, O.; Blondeau, N.; Nahon, J.-L.; Rovère, C. The complex contribution of chemokines to neuroinflammation: Switching from beneficial to detrimental effects. Ann. N. Y. Acad. Sci. 2015, 1351, 127-140. [CrossRef]

61. Nishimura, M.; Kuboi, Y.; Muramoto, K.; Kawano, T.; Imai, T. Chemokines as novel therapeutic targets for inflammatory bow-el disease. Ann. N. Y. Acad. Sci. 2009, 1173, 350-356. [CrossRef]

62. van der Vorst, E.P.; Döring, Y.; Weber, C. Chemokines. Arterioscler. Thromb. Vasc. Biol. 2015, 35, e52-e56. [CrossRef]

63. Nagarsheth, N.; Wicha, M.S.; Zou, W. Chemokines in the cancer microenvironment and their relevance in cancer immuno-therapy. Nat. Rev. Immunol. 2017, 17, 559-572. [CrossRef]

64. Takeuchi, O.; Akira, S. Pattern recognition receptors and inflammation. Cell 2010, 140, 805-820. [CrossRef] [PubMed]

65. Schroder, K.; Zhou, R.; Tschopp, J. The NLRP3 inflammasome: A sensor for metabolic danger? Science 2010, 327, 296-300. [CrossRef]

66. Maedler, K.; Sergeev, P.; Ris, F.; Oberholzer, J.; Joller-Jemelka, H.I.; Spinas, G.A.; Kaiser, N.; Halban, P.A.; Donath, M.Y. Glu-coseinduced beta cell production of IL-1 $\beta$ contributes to glucotoxicity in human pancreatic islets. J. Clin. Investig. 2017, 127, 1589. [CrossRef]

67. Ferrari, S.M.; Fallahi, P.; Ruffilli, I.; Elia, G.; Ragusa, F.; Paparo, S.R.; Patrizio, A.; Mazzi, V.; Colaci, M.; Giuggioli, D.; et al. Immunomodulation of CXCL10 secretion by hepatitis C virus: Could CXCL10 be a prognostic marker of chronic hepatitis C? J. Immunol. Res. 2019, 2019, 5878960. [CrossRef]

68. Singh, K.P.; Zerbato, J.M.; Zhao, W.; Braat, S.; Deleage, C.; Tennakoon, G.S.; Mason, H.; Dantanarayana, A.; Rhodes, A.; Rhodes, J.W.; et al. Intrahepatic CXCL10 is strongly associated with liver fibrosis in HIV-Hepatitis B co-infection. PLoS Pathog. 2020, 16, e1008744. [CrossRef]

69. Nishimura, S.; Manabe, I.; Nagasaki, M.; Eto, K.; Yamashita, H.; Ohsugi, M.; Otsu, M.; Hara, K.; Ueki, K.; Sugiura, S.; et al. CD8+ effector T cells contribute to macrophage recruitment and adipose tissue inflammation in obesity. Nat. Med. 2009, 15, 914-920. [CrossRef]

70. Winer, S.; Chan, Y.; Paltser, G.; Truong, D.; Tsui, H.; Bahrami, J.; Dorfman, R.; Wang, Y.; Zielenski, J.; Mastronardi, F.; et al. Normalization of obesity-associated insulin resistance through immunotherapy. Nat. Med. 2009, 15, 921-929. [CrossRef]

71. Shadidi, K.R.; Aarvak, T.; Henriksen, J.E.; Natvig, J.B.; Thompson, K.M. The chemokines CCL5, CCL2 and CXCL12 play sig-nificant roles in the migration of Th1 cells into rheumatoid synovial tissue. Scand. J. Immunol. 2003, 57, 192-198. [CrossRef]

72. Bahlas, S.; Damiati, L.; Dandachi, N.; Sait, H.; Alsefri, M.; Pushparaj, P.N. Rapid immunoprofiling of cytokines, chemokines and growth factors in patients with active rheumatoid arthritis using luminex multiple analyte profiling technology for precision medicine. Clin. Exp. Rheumatol. 2019, 37, 112-119.

73. Roca, H.; Varsos, Z.S.; Pienta, K. CCL2 Is a negative regulator of AMP-activated proteinkKinase to sustain mTOR Complex-1 activation, survivin expression, and cell survival in human prostate cancer PC3 cells. Neoplasia 2009, 11, 1309-1317. [CrossRef]

74. Hayashi, M.; Iwashita, M.; Nishimura, Y.; Shinjo, T.; Sano, T.; Yamashita, A.; Fukuda, T.; Sanui, T.; Asano, T.; Nishimura, F. Adi-pose-specific C-C motif chemokine ligand (CCL) 19 overexpression drives the mice to both insulin resistance and weight gain. BMJ Open Diabetes Res. Care 2021, 9, e001871. [CrossRef]

75. Joven, J.; Rull, A.; Rodriguez-Gallego, E.; Camps, J.; Riera-Borrull, M.; Hernández-Aguilera, A.; Martin-Paredero, V.; SeguraCarretero, A.; Micol, V.; Alonso-Villaverde, C.; et al. Multifunctional targets of dietary polyphenols in disease: A case for the chemokine net-work and energy metabolism. Food Chem. Toxicol. 2013, 51, 267-279. [CrossRef] [PubMed]

76. Proudfoot, A.E.I.; Handel, T.M.; Johnson, Z.; Lau, E.K.; LiWang, P.; Clark-Lewis, I.; Borlat, F.; Wells, T.; Kosco-Vilbois, M.H. Glycosaminoglycan binding and oligomerization are essential for the in vivo activity of certain chemokines. Proc. Natl. Acad. Sci. USA 2003, 100, 1885-1890. [CrossRef]

77. Sharif, O.; Brunner, J.S.; Vogel, A.; Schabbauer, G. Macrophage rewiring by nutrient associated PI3K dependent pPathways. Front. Immunol. 2019, 10, 2002. [CrossRef]

78. McCormick, B.; Chu, J.Y.; Vermeren, S. Cross-talk between Rho GTPases and PI3K in the neutrophil. Small GTPases 2017, 10, 187-195. [CrossRef]

79. Jiang, H.; Wang, X.; Miao, W.; Wang, B.; Qiu, Y. CXCL8 promotes the invasion of human osteosarcoma cells by regulation of PI3K/Akt signaling pathway. APMIS 2017, 125, 773-780. [CrossRef]

80. Shen, X.; Artinyan, A.; Jackson, D.; Thomas, R.M.; Lowy, A.M.; Kim, J. Chemokine Receptor CXCR4 Enhances Proliferation in Pancreatic Cancer Cells Through AKT and ERK Dependent Pathways. Pancreas 2010, 39, 81-87. [CrossRef]

81. Yang, Z.-Z.; Tschopp, O.; Baudry, A.; Dümmler, B.; Hynx, D.; Hemmings, B. Physiological functions of protein kinase B/Akt. Biochem. Soc. Trans. 2004, 32, 350-354. [CrossRef]

82. Zhang, Y.; Guan, X.-Y.; Jiang, P. Cytokine and Chemokine Signals of T-Cell Exclusion in Tumors. Front. Immunol. 2020, 11, 594609. [CrossRef]

83. Chan, O.; Burke, J.D.; Gao, D.F.; Fish, E.N. The chemokine CCL5 regulates glucose uptake and AMP kinase signaling in activated T cells to facilitate chemotaxis. J. Biol. Chem. 2012, 287, 29406-29416. [CrossRef]

84. Chien, H.-C.; Chan, P.-C.; Tu, C.-C.; Day, Y.-J.; Hung, L.-M.; Juan, C.-C.; Tian, Y.-F.; Hsieh, P.-S. Importance of PLC-Dependent PI3K/AKT and AMPK Signaling in RANTES/CCR5 Mediated Macrophage Chemotaxis. Chin. J. Physiol. 2018, 61, 266-279. [CrossRef] 
85. Loos, T.; Mortier, A.; Gouwy, M.; Ronsse, I.; Put, W.; Lenaerts, J.-P.; Van Damme, J.; Proost, P. Citrullination of CXCL10 and CXCL11 by peptidylarginine deiminase: A naturally occurring posttranslational modification of chemokines and new dimen-sion of immunoregulation. Blood 2008, 112, 2648-2656. [CrossRef]

86. Struyf, S.; Noppen, S.; Loos, T.; Mortier, A.; Gouwy, M.; Verbeke, H.; Huskens, D.; Luangsay, S.; Parmentier, M.; Geboes, K. Citrullination of CXCL12 differentially reduces CXCR4 and CXCR7 binding with loss of inflammatory and anti-HIV-1 activity via CXCR4. J. Immunol. 2009, 182, 666-674. [CrossRef]

87. Proost, P.; Loos, T.; Mortier, A.; Schutyser, E.; Gouwy, M.; Noppen, S.; Dillen, C.; Ronsse, I.; Conings, R.; Struyf, S. Citrullina-tion of CXCL8 by peptidylarginine deiminase alters receptor usage, prevents proteolysis, and dampens tissue inflammation. J. Exp. Med. 2008, 205, 2085-2097. [CrossRef]

88. Barker, C.E.; Thompson, S.; O’Boyle, G.; Lortat-Jacob, H.; Sheerin, N.S.; Ali, S.; Kirby, J.A. CCL2 nitration is a negative regula-tor of chemokine-mediated inflammation. Sci. Rep. 2017, 7, 44384. [CrossRef]

89. Molon, B.; Ugel, S.; Del Pozzo, F.; Soldani, C.; Zilio, S.; Avella, D.; De Palma, A.; Mauri, P.; Monegal, A.; Rescigno, M.; et al. Chemo-kine nitration prevents intratumoral infiltration of antigen-specific T cells. J. Exp. Med. 2011, 208, 1949-1962. [CrossRef]

90. Janssens, R.; Mortier, A.; Boff, D.; Vanheule, V.; Gouwy, M.; Franck, C.; Larsen, O.; Rosenkilde, M.M.; Van Damme, J.; Amaral, F.A.; et al. Natural nitration of CXCL12 reduces its signaling capacity and chemotactic activity in vitro and abrogates intra-articular lymphocyte recruitment in vivo. Oncotarget 2016, 7, 62439-62459. [CrossRef]

91. Metzemaekers, M.; Van Damme, J.; Mortier, A.; Proost, P. Regulation of Chemokine Activity-A Focus on the Role of Dipeptidyl Peptidase IV/CD26. Front. Immunol. 2016, 7, 483. [CrossRef]

92. Proost, P.; Struyf, S.; Van Damme, J.; Fiten, P.; Ugarte-Berzal, E.; Opdenakker, G. Chemokine isoforms and processing in in-flammation and immunity. J. Autoimmun. 2017, 85, 45-57. [CrossRef] [PubMed]

93. Van Lint, P.; Libert, C. Chemokine and cytokine processing by matrix metalloproteinases and its effect on leukocyte migra-tion and inflammation. J. Leukoc. Biol. 2007, 82, 1375-1381. [CrossRef] [PubMed]

94. Monneau, Y.; Arenzana-Seisdedos, F.; Lortat-Jacob, H. The sweet spot: How GAGs help chemokines guide migrating cells. J. Leukoc. Biol. 2015, 99, 935-953. [CrossRef] [PubMed]

95. Salanga, C.; Handel, T. Chemokine oligomerization and interactions with receptors and glycosaminoglycans: The role of structural dynamics in function. Exp. Cell Res. 2011, 317, 590-601. [CrossRef]

96. Dyer, D.P.; Thomson, J.M.; Hermant, A.; Jowitt, T.A.; Handel, T.M.; Proudfoot, A.E.I.; Day, A.; Milner, C.M. TSG-6 inhibits neutrophil migration via direct interaction with the chemokine CXCL8. J. Immunol. 2014, 192, 2177-2185. [CrossRef]

97. Dyer, D.P.; Salanga, C.L.; Johns, S.C.; Valdambrini, E.; Fuster, M.M.; Milner, C.M.; Day, A.J.; Handel, T.M. The an-ti-inflammatory protein TSG-6 regulates chemokine function by inhibiting chemokine/glycosaminoglycan interactions. J. Biol. Chem. 2016, 291, 12627-12640. [CrossRef]

98. Dyer, D.P.; Salanga, C.L.; Volkman, B.F.; Kawamura, T.; Handel, T.M. The dependence of chemokine-glycosaminoglycan interactions on chemokine oligomerization. Glycobiology 2015, 26, 312-326. [CrossRef]

99. Liang, W.G.; Triandafillou, C.G.; Huang, T.-Y.; Zulueta, M.M.L.; Banerjee, S.; Dinner, A.R.; Hung, S.-C.; Tang, W.-J. Structural basis for oligomerization and glycosaminoglycan binding of CCL5 and CCL3. Proc. Natl. Acad. Sci. USA 2016, 113, 5000-5005. [CrossRef]

100. Von Hundelshausen, P.; Koenen, R.R.; Sack, M.; Mause, S.F.; Adriaens, W.; Proudfoot, A.E.I.; Hackeng, T.M.; Weber, C. Heterophilic interactions of platelet factor 4 and RANTES promote monocyte arrest on endothelium. Blood 2005, 105, 924-930. [CrossRef]

101. Koenen, R.R.; von Hundelshausen, P.; Nesmelova, I.V.; Zernecke, A.; Liehn, E.A.; Sarabi, A.; Kramp, B.K.; Piccinini, A.M.; Paludan, S.R.; Kowalska, M.A. Disrupting functional interactions between platelet chemokines inhibits atherosclerosis in hy-perlipidemic mice. Nat. Med. 2009, 15, 97-103. [CrossRef]

102. Von Hundelshausen, P.; Agten, S.M.; Eckardt, V.; Blanchet, X.; Schmitt, M.M.; Ippel, H.; Neideck, C.; Bidzhekov, K.; Leberzammer, J.; Wichapong, K.; et al. Chemokine interactome mapping enables tailored intervention in acute and chronic inflammation. Sci. Transl. Med. 2017, 9, eaah6650. [CrossRef]

103. Miller, M.C.; Mayo, K.H. Chemokines from a structural perspective. Int. J. Mol. Sci. 2017, 18, 2088. [CrossRef]

104. Pezhman, L.; Tahrani, A.; Chimen, M. Dysregulation of Leukocyte Trafficking in Type 2 Diabetes: Mechanisms and Po-tential Therapeutic Avenues. Front. Cell Dev. Biol. 2021, 22, 624184. [CrossRef]

105. Monickaraj, F.; Oruganti, S.R.; McGuire, P.; Das, A. A potential novel therapeutic target in diabetic retinopathy: A chemokine receptor (CCR2/CCR5) inhibitor reduces retinal vascular leakage in an animal model. Graefes Arch. Clin. Exp. Ophthalmol. 2020, 259, 93-100. [CrossRef]

106. Xue, C.-B.; Wang, A.; Han, Q.; Zhang, Y.; Cao, G.; Feng, H.; Huang, T.; Zheng, C.; Xia, M.; Zhang, K.; et al. Discovery of INCB8761/PF-4136309, a potent, selective, and orally bioavailable CCR2 antagonist. ACS Med. Chem. Lett. 2011, 2, 913-918. [CrossRef] 